\title{
Boko Haram Insurgency/Terrorist and its Impact on Nigeria's Economy
}

\author{
Alonge Sylvester ${ }^{*}$, Osimen, Goddy Uwa ${ }^{* *}$ \\ ${ }^{*}$ Department of Political Science, Ambrose Alli University, Ekpoma, Edo \\ ** Department of International Relations \& Diplomacy, Afe Babalola University,Ado-Ekiti \\ DOI: 10.29322/IJSRP.11.12.2021.p12072 \\ http://dx.doi.org/10.29322/IJSRP.11.12.2021.p12072
}

\begin{abstract}
Boko Haram terrorist group has posed a significant security problem to the country. Apart from the fact that the terrorist group has displaced farmers, causing many of them to desert their farms, their activities have equally affected the country's production and trade of goods and services. Boko Haram insurgency has similarly affected the movement of goods and services across the country, especially in the North-eastern states, the exportation of cash and food crops, tourism, and entrepreneurial development, all of which have dire consequences for the country's economy. If Boko Haram's terror is allowed to persist, it could plunge the country into a recession that will take years to recover. Thus, this study examined the effect of the Boko Haram insurgency on Nigeria's economy, with a particular focus on how to curb the menace. The paper utilized secondary data sourced from textbooks, journals, newspapers, and the internet. The paper found that Boko Haram terrorist insurgency harm agricultural productivity, trade, investment, entrepreneurial and industrial development in Nigeria. It therefore recommended that Nigerian government should provide adequate necessities of life such as good hospitals, quality education, motorable roads, portable water, and favourable conditions for employment opportunities to the people of Nigeria, as it will help to enhance employment generation and reduce the rate at which people indulge in the act of terrorism. It also recommended that the government should initiate more strategies or programmes of poverty reduction, as it will help reduce drastically the rate at which some Nigerians indulge in acts of terrorism or other activities capable of enthroning insecurity in the country.
\end{abstract}

Index Terms- Boko Haram, Insurgency, Terrorism, Economy and Nigeria

\section{INTRODUCTION}

A fter gaining independence from the United Kingdom in October 1960, Nigeria experienced instability. Since then the country has been facing various levels of security challenges such as ethnoreligious crises, armed robbery political assassination election violence and militancy. In recent times, another insecurity problem (terrorism) has been added to the ones previously experienced. Terrorism seems to be the primary security problem the country is facing. The level of terrorist attacks in different parts of the country is alarming. Boko haram has been responsible for the act of terrorism in Nigeria. Umaru, Pate and Haruna (2015) confirmed that Nigeria's current and most disturbing insecurity problem is the terror unleashed by Boko Haram. Boko Haram is a dreaded militant Islamic sect popularly known as Jama'atulAlhulSunnahLidda' Wat, Wal Jihad - meaning a group committed to propagating Prophet Muhammed's teachings Jihad (Umaru et al., 2015).

Terrorism refers to the adoption of threat or violence by an individual or group, whether acting for or opposing established authority. Such action is purposely to create extreme anxiety and fear-including effects in a target group more significant than the immediate victims to coerce that group into acceding to the political demands of the perpetrators (Wardlaw, 1982). Terrorist tactics involve suicide bombing, car bombing, rocket-propelled grenades, assassinations, abductions, kidnapping, disguising, and hijacking (Omede and Omede, 2015). The Boko haram terrorists in Nigeria replicate the features of the above definition in their activities. Boko Haram terrorist groups employ violence and target the larger population; when they strike, the number of deaths and casualties is usually massive. Boko Haram terrorist group in Nigeria also indulges in the suicide bombing, car bombing, assassinations, abductions, and kidnapping. The kidnapping of schoolgirls in Chibok, the kidnapping and killing of the Christian Association of Nigerian (CAN) president and the use of female suicide bombers are some reference points.

Boko Haram activities and the insecurity it causes have affected Nigeria's economy. An economy is the vast set of interrelated production and consumption activities that influences the allocation of scarce resources. An economy includes all activities related to the buying and selling goods and services and their consumption in an area. The economy is available to everyone, from individuals to entities such as businesses and governments. According to Stewart (2004), the economic cost of insecurity and acts of terrorism are enormous. Boko Haram activities have negatively affected Nigeria's economy, disrupting business activities and the industrialization process in the country.

Boko Haram insurgency is responsible for the decreased production of goods and services in the country. The sect's insurgency has taken its toll on local businesses, particularly in the three northern states of Adamawa, Borno, and Yobe, where the terrorist group has gained most ground and, by extension, other states depending on the produce from the north. For instance, the local chamber of commerce estimates that business activity in Kano has dropped by $80 \%$ over the past three years. A textile business owner in the city of Kano says: "Lots of projects are being canceled in the region because people are scared. They are scared that factories can become targets; commuters to work can 
also become targets; and this is impacting everyone here" (SriPathma, 2015). In other words, the Boko Haram insurgency has made it difficult or near impossible for the citizens in the Northern part of Nigeria and other states to carry on their legitimate businesses.

Boko Haram insurgency is responsible for the lack of investment in poor communities. Local businessmen and women intending to invest in the Northern part of Nigeria are not doing so due to the fear of the unknown. Many investments in the Northern part of Nigeria have closed down, while their owners have relocated such businesses to safer neighbouring countries. In the same vein, the Boko Haram insurgency is also scaring foreign investors out of the country, adversely affecting foreign direct investment (FDI). There has been a decrease in foreign direct investment in Nigeria. Foreign direct investment (FDI) usually is an investment focused on building new industrial facilities or putting resources into actual generation exercises that create employment. Outside financial investors in the Nigerian economy are moving far from beginning new organisations or creation plants and are purchasing up offers of cited institutions (Jelilov, Ozden and Briggs, 2018).

Boko Haram insurgency is equally responsible for the poor state of agricultural production in Nigeria generally and the North in particular, where agricultural production is their main economic activity. Boko Haram insurgency has led to the displacement of farmers in Northwest and Northeast of Nigeria, thereby making many farmers abandon their farmland in other to save their lives first. To these persons who have left agriculture productivity, it has ceased to be an essential sector at the moment. The resultant effect is that millions of Nigerians now experience food shortages because of the collapse of local agriculture (Matfess, 2017).

Boko Haram insurgency has also affected tourism in Nigeria. Due to the fear of being attacked, visitation to tourist sites in Nigeria has drastically reduced. Worst still, foreign tourists are afraid of visiting Nigeria too for fear of being killed or kidnaped. Act of terrorism by the Boko Haram sect has also caused the shortage of workers with entrepreneurial skills, affecting industrial development in the country.

Infrastructural facilities such as roads, schools and hospitals, have also been destroyed as a result of the Boko Haram insurgency. For instance roads that are destroyed reduced the productive capacity of the economy. In 2016, the World Bank estimated that the insurgency's raids, bombings, and razing of communities throughout the region had caused $\$ 9$ billion worth of destruction (Matfess, 2017). These destructions have dire negative effect on the Nigerian economy.

There is the need to end Boko Haram insurgency in Nigeria, if the country must enjoy a stable economic and development. If Boko Haram sect is allowed to carry on with their activities, they could plunge the economy of Nigeria into recession with dire economic consequences for the citizens and the nation at large. Hence this study is an examination of the impact of terrorism and insecurity on Nigeria economy, using the Boko Haram insurgency as case study.

\section{Statement OF THE Problem}

Boko Haram insurgency had posed a significant security problem to the Nigerian state. It has affected farming; it has disrupted the production of cash crops and food crops such as rice, yam, cassava, maize, millet, sorghum, soya beans, and livestock rearing. Boko Haram insurgency has displaced farmers, and many farmlands have been abandoned. Although some farmers still manage to remain in the farm business, their lives are at stake because the Boko Haram attack can occur at any time. The disruption of the production of cash and food crops and livestock has led to decreases in milk production, meat production, and an increase in cattle price. Poultry farmers also do not find their business lucrative anymore, as the people purchasing the goods have been displaced (Adebisi, Azeez, and Oyedeji, 2016).

Boko Haram insurgency has also affected trade and investment. Boko Haram insurgency has crippled the agricultural export market in northern states, resulting in the forfeiture of one of Nigeria's largest prospective revenue sources. In addition, major markets in the northeast and northwest, where Boko Haram originated from and very active, have become ghost areas due to the sect's activities (Adebisi et al., 2016). The effect of Boko Haram's activities on trade and investment has reduced the country's foreign reserve and has worsened the unemployment problem in the country. Boko Haram insurgency has also affected entrepreneurial development and industrial development in Nigeria, which has further exacerbated the unemployment situation in the country. Allowing the Boko Haram insurgents to persist with their nefarious activities could plunge the country into a recession to take the country years to recover. Thus, the paper examines the effect of the Boko Haram insurgency on Nigeria's economy.

\section{OBJECTIVE OF THE STUDY}

The overall aim of the paper is to examine the impact of terrorism on Nigeria economy with Boko Haram insurgency in perspective. In specific terms, the objectives of the paper are to:

a. examine the impact of Boko Haram insurgency on agricultural productivity in Nigeria,

b. examine the impact of Boko Haram insurgency on trade and investment in Nigeria,

c. examine the impact of Boko Haram insurgency on entrepreneurial and industrial development in Nigeria.

\section{RESEARCH QUESTIONS}

In order to realize the objectives of this paper, the following research questions have been formulated.

a. What is the impact of Boko Haram's insurgency on agricultural productivity in Nigeria?

b. What is the impact of Boko Haram's insurgency on trade and investment in Nigeria?

c. What is the impact of Boko Haram' insurgency on entrepreneurial and industrial development in Nigeria?

\section{THEORETICAL FRAMEWORK}

The study adopts social movement theory to explain the perpetuation of the Boko Haram insurgency in Nigeria. Social movement theory, partly due to its integrative and interdisciplinary nature, is uniquely situated to render explanations to the occurrence of political violence and terrorism (Beck, 2008). The major proponents of this theory are Blumer (1951) and 
Turner and Killian (1972). The nexus of the theory is that when people are dissatisfied with government policies or programmes, they form a social movement to effect change. They erupt aggressive disorderly actions aimed and directed at the state. Prior to the 1970s, most studies of social movements accounted for movement-focused collective behavior as a product of social frustration or stress (Marx and Wood 1975; Smelser 1962). For instance, Gurr (1970) views relative exclusion as the primary factor in the emergence of dispute, and Kornhauser (1959) argues that isolation from mass society encourages individuals to participate in collective action. These classic models chiefly posit a psychological process whereby social situations affect individuals and stimulate them to challenge the status quo (McAdam 1982). In the study of terrorism, frustration and stress continue to play a significant role: argument has shown that terrorism is motivated by threatened values or idealized religious doctrine in contradiction with society's practice (Juergensmeyer, 2003), reactions to the strain of modernization in society (Bendle, 2003), foreign military occupations and external influence (Ayoob, 2005; Pape, 2005), or other broad grievances (Stern 2003).

Apart from grievances, McCarthy and Zald (1973, 1977) argued that sustained collective action, movements depend on material resources and a base of supporters. Jenkins (1983) points out that the fundamental problem of collective action is the resources available for mobilization and their implementation. One strategy for solving resource problems is to build organizational capacity that can gather supporters, seek material support and operate together as a process. In addition, McAdam (1999) pointed out that emerging movements can appropriate existing organizations for collective action. Once a movement occurs, the newly formed organizations often tend to endorse themselves, thereby bringing about a highly professional core that manages and supervises joint operations (McCarthy and Zald, 1977), which helps them survive and adapt to changing environments (Minkoff, 1999).

Another tripartite model of social movement theory is the structure of political opportunities and constraints external to organizations. The concept of political opportunity was invented by Eisinger (1973) and became a means of enabling movement in the broader political environment in which they carry out their operations. Movement happens not only because of successful mobilisation of resources but also because the overall political or social condition is ready for a successful and lasting conflict. Therefore, political process theory argues that political opportunity pools with the ability of organizations to mobilize people for social movement (McAdam 1982). Opportunities for mobilization may result from significant shifts in the overall political structure or events that may provide specific opportunities, such as aggressive action.

Applying the above theory to the emergence of a terrorist group and their sustenance, one will find that terrorist group requires a steady influx of participants. In the case of a terrorist group that adopts suicide bombing as a strategy, they need participants who are willing to die for a cause. Terrorists also need resources and support to undertake sustained campaigns. Social movement theory equally holds that terrorism also depends on the external environment in which the group operates rather than only internal processes. For instance, in an unstable environment without an effective central authority, terrorists can seek safehaven, attract recruits, cage resources, and carry out attacks. AlQaeda in Iraq and other militant organizations arose not just from grievances or the mobilization of resources but because the American invasion demolished centralized authority, creating the opportunity for new mobilization and a threat to established power arrangements (Beck, 2008).

The social movement theory explains the emergence of Boko Haram terrorists and how their activities get sustenance. The Boko Haram sect is a movement that emerged because the group is dissatisfied with government policies and programmes, hence the need to effect a change.

The government's policies and programmes are to solve Nigerian's problems. Nigerian's problems may be referred to as a policy problem. A policy problem is a problem or dissatisfaction, self-identified or identified by others for relief. A policy problem is also a situation that many people consider adverse or intolerable in its effect on many people over a long period. Therefore, people believe such a situation needs a constructive change (Egonmwan, 2000). Unfortunately, most government policies and programmes in Nigeria do not serve the needs of the public, and where such exists, they rarely get the implementation. Nnajiofor, Ifeakor, and Mgbemena (2013) found that most of the policies in Nigeria only exist on paper and are never implemented to actualize the objectives of such policies. It is so because the cabal that holds the top echelon of government hostage, at any point in time, usually jeopardizes or frustrates the implementation of public policies in the country (Egbulefu, 2004). The effect of non-implementation of government policies and programmes is poverty, unemployment, insecurity of life and property, and infrastructural decay, which have remained major country features. More worrisome is that despite the government's policies and programmes, the rich are getting richer, while the poor are getting poorer. The frustration caused by the above situation led to the emergence of Boko Haram to effect the needed change. David, Asuelime, and Onapajo (2016) argued that poverty, joblessness, inequality, lack of infrastructural amenities, and inadequate education are the reasons for the emergence and consistency of the Boko Haram insurgency. Ayegba (2015) also added that poverty and joblessness are the primary triggers behind the rebellion in Nigeria

We can recall that the sect's name, Boko Haram means Western education is a sin. The sect expected the education of the political elites to be an instrument of development for the country, but this was not the case, as corruption, mass looting, oppression, and marginalisation have continued unabated in the country and have contributed to the hardship among Nigerians. So the group emerged to put an end to the anomaly. Mustapha and Hamid (2019) confirmed that the Boko Haram insurgency is not unconnected to poor governance, deep-rooted corruption, and economic marginalization, and which has aided the growth of the radical groups.

Social movement theorists also argued that sustained collective action depends on material resources and a base of supporters. The implication is that the growth and development of the Boko Haram sect have relied on material resources and support from its supporters. As regards human resources, the Boko Haram sect acquire its human resources (fighters) from the numerous unemployed youths, criminals, drug addicts, and the educated, 
whose condition of living has made them dissatisfied with the state. The group also takes advantage of the irresponsible leadership at all levels of government, unemployment, poverty, corruption, and insecurity (Mustapha and Hamid, 2019; Adebayo, 2014). Boko Haram also acquires its human resources from the Almajiris. Parker (2012) also observed that Almajiris provides fertile recruitment grounds for Boko Haram. In an interview, Eneruvie Enakoko, a Nigerian publicist and activist, pointed out that Almajiri schools were partly responsible for the Boko Haram terror (Deutsche Welle, 2020).

Again, the persistence of the Boko Haram sect in Nigeria can equally be attributed to the support accorded to the group from within and outside Nigeria, as pointed out by the social movement theory. Research has shown the existence of links between Boko Haram and Islamic State (IS) groups in Iraq and Syria, Al Qaeda in the Islamic Maghreb, and the Al Shabab group in Somalia (Asemah, 2013). These terrorist groups have been giving various supports, which include money and training to Boko Haram members. For instance, ARIM has been providing training to the Boko Haram terrorist group.

Due to the existing link between Boko Haram and Al-Qaeda in the Islamic Maghreb, the group has been opened to more funding from groups in Saudi Arabia and the UK. Research has it that Al-Muntada Trust Fund, with headquarters in the United Kingdom, had extended some financial assistance to the sect. The sect also financed its nefarious activities through the Islamic world society with headquarters in Saudi Arabia. Some prominent Northern businessmen also make contributions to support the sect's activities (Ndukong, 2012). The solid financial base of the sect has remained the primary reason why all the security agencies sent to the borders cannot resist their largesse. In addition, due to the support from international terrorist groups, it has been observed that Boko Haram leaders pledge allegiance to the Islamic State in Iraq and Syria (BBC News, 2015).

The social movement theory has been able to explain why the Boko Haram insurgency emerged and the persistence of its nefarious activities. Going by the social movement theory, it is evident that Boko Haram seeks to effect a change in how the affairs of the Nigerian state are being steered. However, the group's nefarious activities have persisted because it has access to resources and support from within and outside Nigeria. Eme and Ibietan (2012) also confirmed the fact when they stated that Boko Haram is comprised mainly of non-Nigerian foreigners and that a handful of resentful politicians is funding the group. They added that the terrorist group has expanded beyond its original religious composition to include Islamic militants and criminal elements, and disgruntled politicians.

However, not until the political elites changes their attitude by not embezzling public funds, being accountable and responsive to the people. The change of attitude also includes providing necessities of life such as good hospitals, quality education, motorable roads, and portable water, creating favourable conditions for employment opportunities; Boko Haram terrorism will continue to loom large in the country.

\section{RESEARCH METHOD}

The study adopted ex-post facto research design (after the event). This research design explained the impact of Boko
Haram's terrorism insurgency on Nigeria's economy looking at events that has already occurred and documented. This research adopted other methods which include analytical and historical approach of study with emphasis on documentary as well as library research. It makes use of data obtained from secondary sources such as reports, books, journals, newspapers, and publications by both governmental and non-governmental organizations and the Internet; hence it is a qualitative research. Qualitative research is a method of inquiry that produces results in words rather than statistics (Bello, 2007 cited in Othman, Sule, and Singh, 2015). Having relied on secondary data, the data collected were analysed qualitatively. Thus, content analysis method analysis since it does not observe people directly; rather it looked at the communication that people have already produced. The method was employed in the study to ensure the maximum extraction of the relevant information from the materials. The units of analysis were text books, paragraphs, broadcasts, newspapers, speeches, minutes of meetings magazines, and the internet.

\section{DISCUSSION}

\section{Boko Haram Insurgency and its impact on Agricultural Production in Nigeria}

Boko Haram Terrorism and the insecurity it causes have negatively affected food crops, cash crops, and livestock production in Nigeria. The insecurity caused by Boko Haram Terrorism has also taken a heavy toll on the quality and quantity of farm produce. Research has shown that over five million Nigerians need food because insecurity limits production (Ojewale, 2019). It is equally on record that Nigeria had about 50 percent of West Africa's food insecure population in 2019 (Nextier SPD, 2020). Boko Haram insurgents make it difficult for most people to venture into their farms. On a visitation to farmers by Business Day in Borno and Yobe in 2018, the farmers and some of their leaders complained of fear due to insecurity, preventing them from returning to the farms to resume food production (Ojewale, 2019). Hence, many farmers have relocated to other places where there is peace to save their lives, causing them to leave their farmlands behind since they cannot carry it along with them (Mustapha, 2015). For over seven years, farming activities have not taken place in the whole of Borno state; the people have depended on the largesse of Dangote and others (Ojewale, 2019). As a result, Nigeria is losing $\$ 10$ billion annually in its exports from peanuts, palm oil, cocoa and cotton as production of these commodities continues to decline (Faminu, 2020). Again, the disruption of farming by the Boko Haram sect has negatively affected food security, and this has dire consequences for Nigeria, especially at this period the country is banning food importation. The Global Report on the Food Crisis listed Nigeria as one of the eight countries with the worst food crises of 2018, which jointly accounted for two-thirds of the entire number of people confronted with acute food insecurity - amounting to nearly 72 million people. Three million people were acutely food insecure in the three north-eastern states affected by the Boko Haram insurgency, where protracted conflict and mass displacement have disrupted agriculture, trade, markets, and livelihoods and forced food prices to increase (Ojewale, 2019).

Ovbiously, if the insecurity caused by Boko Haram is not urgently addressed, its impact on agricultural productivity has the 
potential of increasing the rate of poverty and hunger in the country. The Vanguard newspaper in its editorial of April, 25, 2019, entitled "The looming hunger, poverty time bomb", noted that the widespread hunger approaching famine has been worsened by an escalation of insecurity across the land. It further pointed out that the whole food belts of Nigeria have been cordoned by violent armed groups, resulting in the dislodgments of many farming communities. The newspaper therefore warned that insecurity is fuelling poverty and hunger in a way never seen before, not even during the Nigerian Civil war (Fasan, 2019).

Ovbiously, if the insecurity caused by Boko Haram is not urgently addressed, its impact on agricultural productivity could increase the rate of poverty and hunger in the country. The Vanguard newspaper, in its editorial of April 25, 2019, entitled "The looming hunger, poverty time bomb," noted that the widespread hunger approaching famine had been worsened by an escalation of insecurity across the land. It further pointed out that the whole food belts of Nigeria have been cordoned by violent armed groups, resulting in the dislodgments of many farming communities. The newspaper warned that insecurity has been worsening poverty and hunger in a manner not experienced during the Nigerian Civil War (Fasan, 2019).

\section{Boko Haram Insurgency and its Impact on Trade and Investment in Nigeria}

Boko Haram terrorism and its attendant insecurity is a significant constraint to trade and investment in Nigeria. The Nigerian economy comprises local and international investors. No matter how small or big these investors are, they all want to make a profit on their investments by delivering viable goods and services that will eliminate scarceness in the marketplace. The total investment from local investors amounts to over 15 million Micro, Small, and Medium Enterprises (MSMEs), much more than the foreign investments. Unfortunately, most of these local investments in the business are not captured in the country's statistics (Alawode, 2014). Such businesses comprise young Nigerians who graduated from higher institutions or have acquired proficient vocational skills but cannot find white-collar jobs. Such persons resort to their families or relatives for money to start a business. No matter how small they may appear, such businesses provide jobs for the most number of Nigerians. Such businesses also pay between N10 000 to N100 000 per month as salaries, helping many Nigerians and their families keep hunger away in food-on-the-table and roof-over-their-heads. The aggregate impact of these businesses on Nigeria's economy is far more than the impact of foreign investors on the country's economy. The 2011 world investment report of the United Nations Conference on Trade Development reported that the disruption of business activities caused by Boko Haram attacks in Kano alone had cost the Nigerian economy N1.3 trillion ( 6 billion dollars) (Aro, 2011).

Unfortunately, businesses are worst hit by the insecurity caused by the Boko Haram sect. For instance, the famous Monday Market, which happens to be the biggest Maiduguri, the capital city of Borno state, was hit by the Boko Haram insurgents, and the effect on the market led to the closure of over 10,000 shops at an early hour (Awortu, 2015; Oshio, 2009). Again, in 2012 the cattle market in the Yobe state town of Potiskum, which used to be among the largest in West Africa, was attacked twice by the Boko
Haram insurgents; more than 100 people died in that attack therein. Presently, it is a ghost market (Ahmed and Eckel, 2014). The insecurity caused by the Boko Haram insurgency has also affected the telecommunication business in Nigeria, especially the northeastern part of the country. Telecom masts were destroyed by insurgents, making communications difficult in these areas (Faminu, 2019). Due to the insecurity situation, telecommunication operators no longer provide service in the North East because any time they put up a mast, it is immediately vandalised by Boko Haram members. The insurgents destroyed more than 25 telecommunication masts and base stations in Maiduguri, Potiskum, Bauchi, Gombe, and Kano states, thereby setting back efforts to improve telecommunications in the region (Awortu, 2015). Consequently, no profitable business can take place in such a situation. It cost millions of naira to replace the vandalised equipment, and no firm will want to take such risk or risk the lives of personnel that have to work in such areas. Okwueze (2015) noted that the activities of members of this group had raised critical questions among investors on the safety of their investments in Nigeria. The group's activities range from killing innocent Nigerians, raping women to bombing major cities and police stations in the northern part of Nigeria, particularly Borno, Kano, Bauchi, Niger, Yobe, Adamawa, Abuja, among others.

In addition, Boko Haram's terror and the insecurity that goes with it has negatively affected transportation, thereby hindering the transport of products by traders from one community or state to another, which is necessary for business activities. For instance, traders from different parts of the country, especially the East, have always traveled in lorries to Adamawa, Borno, and other Northern states to buy farm produce which they take back to every other part of the country to sell. This trade worth billions of naira annually has been disrupted as many traders can no longer continue with their businesses due to the Boko Haram insurgency. The reduction in mobility of goods and services is because traders are afraid of the terror unleashed by the Boko Haram sect. Supporting the above fact is Faminu (2020), who opined that violent conflicts like the one executed by the Boko Haram group negatively affect transportation services, particularly road transportation, which, in turn, constrains freight movement and haulage activities needed to move goods and services around the country. The impact of the insecurity caused by Boko Haram on trade in Nigeria made Abdulrasaq Balogun, secretary to Lagos State Security Trust Fund (LSSTF) to state that without adequate security, businesses will not thrive (Faminu, 2019). Concerning the above fact, Adebayo (2014) found that when people feel insecure, their appetite to invest, to buy, or rent from the product of investment reduces.

\section{Boko Haram Insurgency and its impact on Entrepreneurial and Industrial Development in Nigeria}

The insecurity caused by Boko Haram Terrorism has negatively affected entrepreneurial and industrial development in Nigeria. Confirming this fact is the Manufacturers Association of Nigeria (MAN), which highlighted insecurity as one of the challenges of local manufacturers in the country (Faminu, 2020). Othman, Sule, and Singh (2015) also observed that the Boko Haram insurgency has left businessmen and companies with no options but to fold up. Apart from the mayhem unleashed directly by the insurgents, the frequent confrontation between the 
insurgents and the police force usually results in the killing and destruction of businessmen and women's properties. This has made people, particularly those from the southern parts of Nigeria, fly from the region, abandoning their business ventures (Adejumola and Tayo, 2012 cited in Othman et al., 2015). The situation is deplorable because the insurgent attacks mainly occur in the rural areas and local communities where economic activities are majorly conducted, primarily where large quantities of food productions are carried out.

Boko Haram terrorists target small business operators, and manufacturers they feel are selling forbidden goods to Muslims. On surviving the Boko Haram attacks, some of these small business owners relocate their businesses to safer regions where they can be safeguarded from Boko Haram destruction. In addition to moving their business, they also go with the taxes they pay to state and local governments, including the employment of indigenes, which automatically reduces. The situation becomes worse when owners of such businesses lose their lives in such attacks or cannot continue such businesses, as there will be a decline in the supply of products of the industry whose owner has been killed. Boko Haram terrorism leads to the disruption of SMEs and prevents the entrant of new entrepreneurs into the industrial sector. This has a deleterious ricocheting impact on industrial development in Nigeria.

Boko Haram insurgency has also caused the mass exodus of skilled entrepreneurs to safer neighbouring countries to establish their business. Many of these professional entrepreneurs move out of the trouble areas because they are tired of the threat to their lives, properties, and businesses. The emigration of these experienced entrepreneurs to safer neighbouring countries starves other industries in the country of the needed workforce to run their business processes. The situation is responsible for the scarcity of skilled entrepreneurs or the high cost of hiring them. Again, the case is also responsible for the death or discontinuation of the business or an entire industry in the country.

As a result of the insecurity caused by Boko Haram, many industries have relocated factories from insecure to secure locations (Faminu, 2020), mainly safe neighbouring countries. Imhonopi and Urim (2016) also observed the mass exodus of large corporations and small, medium enterprises (SMEs) to commercial centers outside terror hot spots to preserve investments and business. Odita and Akan (2014) argued that Boko Haram's insurgency had disrupted economic activities in Nigeria to no small extent.

\section{CONCLUSION AND RECOMMENDATIONS}

The study has successfully examined terrorism and its impact on Nigeria economy, using the Boko Haram insurgency as case study. The analysis revealed that Boko Haram insurgency and the insecurity associated with it, impacts Nigeria's economy negatively. The economy of Nigeria has been adversely affected by the Boko Haram insurgency. It has impacted agricultural production negatively in Nigeria. Currently, the terrorist group has hampered the once thriving agricultural activities in Adamawa, Taraba, Yobe, Bauchi, Kano, Katsina, Plateau, Gombe, Borno, and the country's capital Abuja, as people have abandoned their farms and have relocated to safer neighbouring countries or states. The activities of the terrorist group has also created fear among farmers living in neighbouring states, as they are now afraid of going to their farms due to the fear of being attacked by the Boko Haram members.

Boko Haram terrorism has negatively impacted trade, as well as repelled investment initiatives from both the international and local investors. It has equally impacted Small and Medium Enterprises (SMEs), entrepreneurial and industrial development negatively in the country. As a result of the Boko Haram terrorism and the insecurity associated with it, foreign and local investors are afraid to set up factories due to the fear of attacks that may make them lose their business. The situation has worsened the level of unemployment and poverty amongst the Nigerian citizens and which in most cases has been pin pointed as responsible for crime increase in the country.

The greatest desire of Nigerians is for the federal government to put an end to the mindless Boko Haram terrorism, so as to restore peace in various states of the country, especially the state mostly dominated by the terrorist group. Hence, the recommendations below are imperative:

Winning the war against the Boko Haram requires more than military action; Government should provide adequate basic necessities of life such as good hospitals, quality education, motorable roads, portable water, and favourable conditions for employment opportunities that can make life meaningful to the people of Nigeria. This in turn will help to enhance employment generation and calm the anger of the terrorist group and forestall the emergence of future terrorist group.

There is the need for government to initiate more strategies or programmes of poverty reduction in Nigerians. There is also the need to reform and strengthen previous programmes targeted at reducing poverty in the country. This will help to drastically reduce the rate at which most Nigerians indulge in act of terrorism or other activities capable of enthroning insecurity in the country. There should be corporal punishment for politicians and other public office holders found guilty of corrupt act or embezzling public funds. This will help to make funds available for government to adequately provide good public services and basic amenities to the Nigerian citizens.

Nigerian government should engage in aggressive use of modern technology in the fight against Boko Haram terrorist group. This includes the use of intelligence that will enable the members of the security forces to detect and foil plans of the terrorists, thereby making it difficult for them to execute their plans.

Therefore, this study emphasize that if the recommendations proffered in this study are strictly applied, the menace of Boko Haram insurgency will be a thing of the past in Nigeria.

\section{REFERENCES}

[1] Adebayo, A. A. (2014). Implications of 'Boko Haram' terrorism on national development in Nigeria: A critical review. Mediterranean Journal of Social Sciences, 5(16), July.

[2] Adebisi, S. A., Azeez, O. O. \& Oyedeji, R. (2016). Appraising the effect of Boko Haram insurgency on the agricultural sector of Nigerian business environment. Journal of Law and Governance, 11(1).

[3] Ahmed, I. \& Eckel, M. (2014). In the home of peace, a siege of fear. Boko Haram: A VOA SpecialReport. Retrieved from https://www.voanews.com/MediaAssets2/projects/bokoharam/index_en.html, 27th May, 2021. 
[4] Alawode, O. (June 23, 2014). How insecurity re-draws Nigeria's business map. Business Day. Retrieved from https://businessday.ng/enterpreneur/article/how-insecurity-re-drawsnigerias-business-map/, 4th May, 2020.

[5] Aro, O. I. (2013). Boko Haram Insurgency in Nigeria: Its implication and way forward toward avoidance of future insurgency. International Journal of Scientific and Research Publications, 3 (11) 1-8.

[6] Asemah, E. S. (2013). Public perception of mass media framing of terrorism in Nigeria: Implication for National Unity, Journal of Communication and Language Arts, 1.

[7] Awortu, B. E. (2015). Boko Haram insurgency and the underdevelopment of Nigeria. Research on Humanities and Social Sciences, 5(6), 213 - 220.

[8] Ayegba, U. S. (2015). Unemployment and poverty as sources and consequence of insecurity in Nigeria: The Boko Haram insurgency revisited. African Journal of Political Science and International Relations 9(3).

[9] Ayoob, M. (2005). The future of political Islam: The importance of external variables. International Affairs, 81, 951-61.

[10] BBC News (2015). Nigeria's Boko Haram pledges allegiance to Islamic State. BBC 7 March. Retrieved from https://www.bbc.com/news/worldafrica-31784538, 4th May, 2020.

[11] Beck, C. J. (2008). The contribution of social movement theory to understanding terrorism. Sociology Compass 2(5), 1565-1581. 10.1111/j.1751-9020.2008.00148.x.

[12] Bendle, M. F. (2003). Militant religion and the crisis of modernity: A new paradigm. Research in the Social Scientific Study of Religion, 14.

[13] Blumer, H. (1951). Collective hehavior. In Alfred McClug Lee, A. (Ed.). New Outline of the Principles of Sociology. New York: Barnes and Noble Books.

[14] David, O. J. Asuelime, L. E. \& Onapajo, H. (2015). Boko Haram: The socioeconomic drivers. Switzerland: Springer.

[15] Deutsche Welle (2020). Nigeria's Almajiri schools: Recruitment ground for terrorists? Deutsche Welle. Retrieved from https://www.dw.com/en/nigeriasalmajiri-schools-recruitment-ground-for-terrorists/a-17521389, 2nd May, 2019.

[16] Egbulefu, T. (April 6, 2009). Forces of darkness. The Source Magazine, 16.

[17] Egonmwan, J. A. (2000) Public Policy Analysis: Concepts and Applications (Revised Edition) Benin City: Res yin (Nig.) Company.

[18] Eisinger, P. K. (1973). The conditions of protest behavior in american cities. American Political Science Review, 67.

[19] Eme, O. I. \& Ibietan, J. (2012). The cost of Boko Haram activities in Nigeria. Arabian Journal of Business and Management Review (OMAN Chapter), 2(2), September.

[20] Faminu, G. (2020). Nigerian economy loses $\$ 121 \mathrm{~m}$ to insecurity, conflictsLCCI. Business Day, 3rd February. Retrieved from https://businessday.ng/real-sector/article/nigerian-economy-loses-121m-toinsecurity-conflicts-lcci/, 27th May, 2021.

[21] Fasan, O. (May 20,2019). Nigeria's economy is comatose, endless insecurity can kill it off. Business Day. Retrieved from https://businessday.ng/columnist/article/nigerias-economy-is-comatoseendless-insecurity-can-kill-it-off/, 4th May, 2020.

[22] Faminu, G. (2019). How insecurity impacts business. Business Day, 31st January. Retrieved from https://businessday.ng/why-nigeria-isbroke/article/how-insecurity-impacts-business/, 27th May, 2021.

[23] Gurr, T. R. (1970). Why men rebel. Princeton, NJ: Princeton University Press.

[24] Jelilov, G., Ozden, K. \& Briggs, S. O. (2018). Impact of insecurity on investment in Nigeria. Journal of Management, Economics, and Industrial Organization, 2(3). http://doi.org/10.31039/jomeino.2018.2.3.3

[25] Jenkins, J. C. (1983). Resource mobilization theory and the study of social movements. Annual Review of Sociology, 9.

[26] Juergensmeyer, M. (2003). Terror in the mind of God: The global rise of religious violence. California: University of California Press.

[27] Kornhauser, W. (1959). The Politics of Mass Society. Glencoe, IL: The Free Press.

[28] Marx, G. T. \& Wood, J. L. (1975). Strands of theory and research in collective behavior. Annual Review of Sociology, 1.

[29] Matfess, H. (2017). How Nigeria's Boko Haram crackdown harms local economies: Harsh trade restrictions have revived smuggling. Council on Foreign Relations, Inc., July 17. Retrieved from

This publication is licensed under Creative Commons Attribution CC BY.

http://dx.doi.org/10.29322/IJSRP.11.12.2021.p12072 https://www.foreignaffairs.com/articles/africa/2017-07-17/how-nigeriasboko-haram-crackdown-harms-local-economies, 23rd January, 2020

[30] McAdam, D. (1982). Political process and the development of black insurgency. 1930-1970. Chicago: University of Chicago Press.

[31] McAdam, D. (1999). Introduction to the second edition. In McAdam, D. (ed.). Political process and the development of black insurgency 1930-1970, 2nd edn. Chicago, IL: University of Chicago Press.

[32] McCarthy, J. D. \& Zald, M. N. (1973). The trends of social movements in America: Professionalization and resource mobilization. Morristown, NJ: General Learning Press.

[33] McCarthy, J. D. \& Zald, M. N. (1977). Resource mobilization and social movements: A partial theory. American Journal of Sociology, 82.

[34] Minkoff, D. C. (1999). Bending with the Wind: Strategic Change and Adaptation by Women's and Racial Minority Organizations. American Journal of Sociology, 104.

[35] Mustapha, M. \& Hamid, A. F. A. (2019). Governance as the bane of Boko Haram insurgency in Nigeria. International Journal of Recent Technology and Engineering (IJRTE), 8(2S9), September.

[36] Ndukong. K. H. (2012). Latest news on those who fund Boko Haram Retrieved from http://digitalizenigeria.com/2012/02/15/latest-newsthosewho-fund-boko-haram-uncovered/. 15th May, 2020.

[37] Nextier SPD (2020). Nigeria's food problem. Nextier SPD (Security, Peace and Development), 4th June. Retrieved from https://nextierspd.com/nigeriasfood-problem/, 10th April, 2021.

[38] Nnajiofor, O. G., Ifeakor, C. S. \& Mgbemena, S. (2013). Nigeria and the enigma of policy implementation. Creative Artist: A Journal of Theatre and Media Studies, Vol. 7 No. 2 (2013) 224-241. Retrieved from https://www.ajol.info/index.php/cajtms/article/view/117048, 23rd May, 2020.

[39] Odita, A. \& Akan, D. (2014). Boko Haram activities: A major setback to Nigeria Economic growth. IOSR Journal of Economics and Finance (IOSRJEF), 3(5), 01-06, May-June.

[40] Ogbonna, C. C. \& Jiménez, J. Á. R. (2017). The inordinate activities of Boko Haram: A critical review of facts and challenges. RIPS. Revista de Investigaciones Políticas y Sociológicas, 16(2), 9-2.

[41] Ojewale, C. (2019). Insecurity makes food security harder for over $5 \mathrm{~m}$ Nigerians. Business Day, 5th April. Retrieved from https://businessday.ng/agriculture/article/insecurity-makes-food-securityharder-for-over-5m-nigerians/, 27th May, 2021.

[42] Okwueze, N. G. (2015). The management of internal security issues in Nigeria: Challenges and prospects. A Seminar Paper, Presented to the Department of Political Science, Ambrose Alli University, Ekpoma, In Partial Fulfilment Of The Requirement for the Award of Ph.D in Strategic Studies, April.

[43] Omede, J. \& Omede, A. A. (2015). Terrorism and insecurity in Nigeria Moral, values and religious education as panaceas. Journal of Education and Practice, 6(11).

[44] Oshio, E. (2009). The Challenge of National Security and Development. Being a paper delivered at the Delta State Christia Professional League Seminar on Crisis Management and Nation Building at Grand Hotel, Asaba.

[45] Othman, M. F., Sule, I. Z. O. \& Singh, R. S. D. (2015). An analysis of the impact of Boko Haram insurgents on business entrepreneurship environment in Nigeria. Academic Journal of Interdisciplinary Studies, 4(3), 37 - 44, November.

[46] Pape, R. A. (2005). Dying to Win: The Strategic Logic of Suicide Terrorism. New York: Random House.

[47] Parker, G. (2012). Nigeria's abandoned youth: Are they potential recruits for militants? Time, February 18. Retrieved from http://content.time.com/time/world/article/0,8599,2107102,00.html, 2nd May, 2019.

[48] Smelser, N. (1962). Theory of collective behavior. New York: The Free Press

[49] Sri-Pathma, V. (2015). Nigeria's 'champagne' economy bucks Boko Haram effect. Business reporter, BBC World Service, 27 March. Retrieved from https://www.bbc.com/news/business-32069880, 23rd January, 2020.

[50] Stem, J. (2003). Terror in the name of God: Why religious militants kill. New York: HarperCollins.

[51] Stewart, F. (2004). Development and security. Working Paper 3, Centre for Research on Inequality, Human Security and Ethnicity, CRISE Queen Elizabeth House, University of Oxford. 
[52] Turner, R. \& Killian, L. (1972). Collective behavior. Second Edition. Englewood Cliffs, NJ: Prentice-Hall.

[53] Umaru, A., Pate, H. A. \& Haruna, A. D. (2015). The impact of insecurity and poverty on sustainable economic development in Nigeria. International Journal of Humanities Social Sciences and Education (IJHSSE), 2(2), February.

[54] Wardlaw, G. (1982). Political terrorism: Theory, tactics and counter measures. Cambridge: University Press.

\section{AUTHORS}

First Author - Alonge Sylvester, Department of Political Science, Ambrose Alli University, Ekpoma, Edo State Email: alongesylvester@aauekpoma.edu.ng-Phone No: 08059977892

Second Author - Osimen, Goddy Uwa, Department of International Relations \& Diplomacy, Afe Babalola University,Ado-Ekiti, Email: goddos4real@ gmail.com- Phone+234-8033-720-666 